\title{
Interspecies Selective Motoneuron Projection Patterns in Chick-Quail Chimeras
}

\author{
Hideaki Tanaka ${ }^{1}$ and Lynn T. Landmesser \\ Department of Physiology and Neurobiology, The University of Connecticut, Storrs, Connecticut 06268
}

\begin{abstract}
During normal development chick motoneurons have been shown to project selectively to appropriate muscles by responding to a series of cues, both specific and nonspecific, within the limb. We tested the ability of motoneurons from another avian species, the Japanese quail, to respond to these cues by transplanting chick limb buds onto quail embryos and quail limb buds onto chick embryos between stages $171 / 2$ and 19 . Feulgen staining, which distinguishes chick from quail cells on the basis of nuclear chromatin, revealed that all limb tissue, including muscle, was of donor origin, indicating that the migration of somitederived muscle precursor cells had been completed by the time of transplantation.
\end{abstract}

Normal quail motoneuron pools for most muscles were located in the same relative positions as homologous chick pools. In chick-quail chimeras we found that the motoneuron pools of one species selectively innervated the homologous muscles in the limb of opposite species with considerable precision. This was determined by defining the segmental innervation pattern of the muscles electrophysiologically and by retrogradely labeling motoneuron pools with HRP. Selective innervation was confirmed by using the functional activation patterns of the motoneuron pools as an additional means of identifying motoneurons. We conclude that any limb-derived cues required by motoneurons to project to their appropriate muscles must be similar in chick and quail and that the growth cones of both species must have similar detector systems for responding to these cues.

Only 7 spinal segments were found to innervate the quail limb (versus 8 for the chick), resulting in an anterior shift in the spinal segments innervating several posterior quail muscles. In chick-quail chimeras these muscles were innervated by segments that innervate the homologous muscle in the opposite species and, therefore, by different segments than would normally innervate them. These observations are discussed with respect to the way that positional values might be assigned to cells in the developing lumbosacral cord and hindlimb, and it is suggested that these results are incompatible with the assignment of positional values on a strict segmental basis.

Motoneurons innervating chick hindlimb muscles are precisely connccted with specific muscles and consistently form discrete

\footnotetext{
Received Oct. 2, 1985; revised Mar. 10, 1986; accepted Mar. 17, 1986.

We thank Ralph Somes, Department of Nutritional Sciences, The University of Connecticut, for providing quail eggs, Sara Putnam for her secretarial support, Mary Jane Spring for help with the illustrations, and Guillermo Pilar, Lisa Dahm, and Steve Meriney for critical evaluation of the manuscript

This work was supported by NIH Grant NS 19640 (I .T.T. .). H.T. was supported by the foreign study program of the Japanese Ministry of Education, Science, and Culture and a fellowship from the Muscular Dystrophy Association.

Correspondence should be addressed to Lynn T. Landmesser, The University of Connecticut, Department of Physiology and Neurobiology, 75 North Eagleville Road, Rm. 416, U-42, Storrs, CT 06268.

${ }^{1}$ Present address: Department of Pharmacology, Gunma University School of Medicine, Maebashi 371, Japan.

Copyright (C) 1986 Society for Neuroscience $0270-6474 / 86 / 102880-09 \$ 02.00 / 0$
}

clusters, or motoneuron pools, in a characteristic position in both the rostrocaudal and transverse plane of the lateral motor column (Hollyday, 1980; Landmesser, 1978a). These motoneurons have been shown to selectively innervate their target muscles even from very early developmental stages (Hollyday, 1983; Landmesser, 1978b; Landmesser and Morris, 1975), and even if the positions of motoneurons in the cord or target muscles in the limb have been altered by small cord reversals (Lance-Jones and Landmesser, 1980b), small anterior-posterior (Lance-Jones and Landmesser, 1981b), or dorsal-ventral limb shifts (Ferguson, 1983), and anterior-posterior reversal of the wing (Stirling and Summerbell, 1983). Further, deletion of some spinal cord segments (Lance-Jones and Landmesser, 1980a) or limb segments (Whitelaw and Hollyday, 1983) does not alter this selective innervation. Based on these results, it has been proposed that motoneurons are specified for particular peripheral targets prior to axonal outgrowth and that there exist in the limb chemical cues that motoneurons can use to selectively grow to their targets (Ferguson, 1983; Lance-Jones and Landmesser, 1980a, b, 1981a, $\mathrm{b}$; Whitelaw and Hollyday, 1983). It is possible that the purported chemical cues would be similar between related species, allowing motoneurons from one species to selectively innervate homologous muscles in a limb from a related species. We tested this possibility for avian lumbosacral motoneurons by creating chick-quail chimeras.

Chick-quail chimeras have been successfully used to analyze other developmental processes, specifically neural crest migration and differentiation (Le Douarin, 1980, 1982). In these experiments, it has been assumed that the migration patterns of ncural crest cells of onc species transplanted into the second species are identical to normal patterns. There have been, however, only a few reports describing selective neural innervation between species. After transplantation of quail eyes into the chick, quail retinal fibers grew to the chick tectum and subserved an at least partially functional pupillary light reflex (Heaton, 1973). It was recently reported that chick retinal fibers were able to grow to quail tectum transplanted either homo- or heterotopically (Alvarado-Mallart and Sotelo, 1984). Finally, Harris (1980) has shown in amphibia that eyes from one species of salamanders can form at least roughly correct retinotopic projections on the tectum of a second species. In the visual system, it is generally agreed (Fraser and Hunt, 1980) that much of the detailed ordering of the retinal-tectal projection results from interactions between retinal afferents.

Therefore, while the above reports indicate that the general cues defining spatial axes are similar between 2 related species, we considered it worthwhile to investigate interspecies neural projections in a system where the connectivity of individual motoneuron pools could be assayed in more detail, and in which motoneurons must diverge from one another and respond to a series of cues, both specific and nonspecific, in forming their appropriate projection patterns (Landmesser, 1984). Although quail have smaller hindlimbs than chicks, the limbs are composed of homologous muscles with very similar spatial arrange- 
ments (Tanaka and Landmesser, 1986). Therefore, we created chick-quail chimeras by transplanting legs between species and assessed motoneuron projection patterns by electrophysiological means and by retrograde labeling of motoneurons with HRP, first in normal quail and then in chick-quail chimeras.

We found that the segmental innervation patterns and motoneuron pool distributions in the quail are very similar to the chick, with only some minor exceptions, and, further, that chick or quail motoneurons were able to selectively innervate homologous muscles in the limb of the opposite species. This suggests that there are common chemical cues in chick and quail limbs and/or that motoneurons can respond to the cues of different species. The chick-quail chimera is therefore a good system in which to examine the dependency of motoneuron cell death on target size, because motoneurons selectively innervate homologous muscles of different size. Cell death of lumbosacral motoneurons in quail and chick-quail chimeras is reported in the accompanying paper (Tanaka and Landmesser, 1986). A preliminary report of these findings has been published in abstract form (Tanaka and Landmesser, 1984).

\section{Materials and Methods}

\section{Embryonic surgery}

Fertile White Leghorn chick and Japanese quail eggs were incubated in a forced-draft incubator at $38^{\circ} \mathrm{C}$. At stages $16^{1 / 2}-19$, as defined by Hamburger and Hamilton (1951), and using the same criteria for quail embryos, embryonic surgery was performed on 203 embryos (98 chick hosts, 105 quail hosts) in a sterile box. (Most of the embryos actually reported on in the present study were operated on between stages $17 \frac{1}{2}$ and $181 / 2$.) A small hole was made in the shell, the shell membrane and amnion opened, and the right limb bud of a chick or quail embryo was transplanted to the right side of an embryo of the other species, the right limb bud of which had been previously removed. Following the operation, the hole in the egg was sealed with a coverslip and the egg returned to the incubator until stages $25-38$. Of these embryos, 76 survived to these stages and developed essentially normal limbs; of these, we studied 31 embryos further. The remaining embryos were used in the study reported in the accompanying paper.

\section{Electrophysiology}

Embryos were decapitated and eviscerated, and a ventral laminectomy was performed after placing the embryos in a bath of oxygenated Tyrode solution at room temperature $\left(18-22^{\circ} \mathrm{C}\right)$. The limbs were skinned and the muscles freed of connective tissue. The sciatic and crural plexuses were usually dissected so that the spinal nerve contribution to each could be visualized. To determine the peripheral projection patterns of quail and chick-quail chimeras, the electrical activity resulting from spinal nerve stimulation was recorded with a suction electrode from each muscle at room temperature. For recording the activation patterns of motoneuron pools during movement sequences, the embryos were left for several hours in oxygenated Tyrode solution at ca. $30^{\circ} \mathrm{C}$. The thoracic or cervical cord was then stimulated with single shocks at 10 min intervals, each shock setting off a sequence of hindlimb kicks. The EMG activity associated with these kicks was recorded with suction electrodes. Detailed electrophysiological techniques have been described previously (Landmesser, 1978a; Landmesser and O'Donovan, 1984a).

\section{Anatomical analysis}

To determine the location of motoneurons innervating a particular muscle, we labeled them retrogradely with HRP. After pressure injection of $10 \% \mathrm{HRP}$ into the muscle, the embryos were incubated for $5 \mathrm{hr}$ at $33-$ $34^{\circ} \mathrm{C}$ and then the cord and limb were fixed in $2 \%$ glutaraldehyde. The cords were processed, reacted for HRP, and sectioned according to the previously published procedures (Landmesser, 1978a). The tcmperature of the $5 \mathrm{hr}$ incubation was found to be critical for obtaining a granular HRP reaction product, which facilitates identification of labeled motoneurons. In chick embryos, such granular staining was obtained as low as $32^{\circ} \mathrm{C}$ as previously reported (Landmesser and O'Donovan, 1984b),
A. ISCHIO

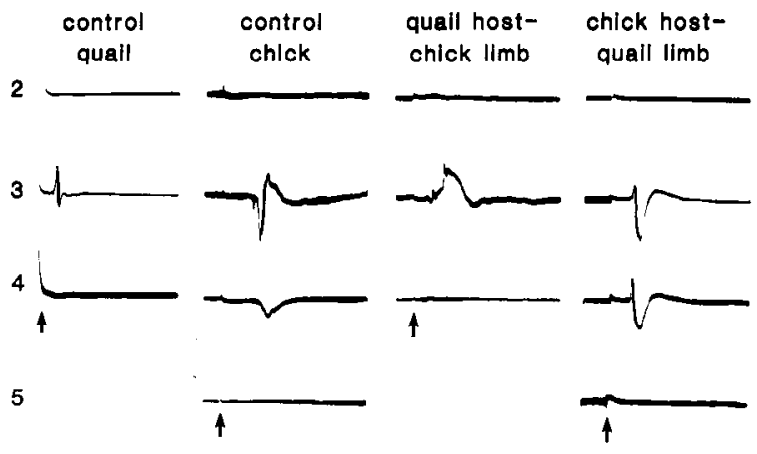

B. CAUD

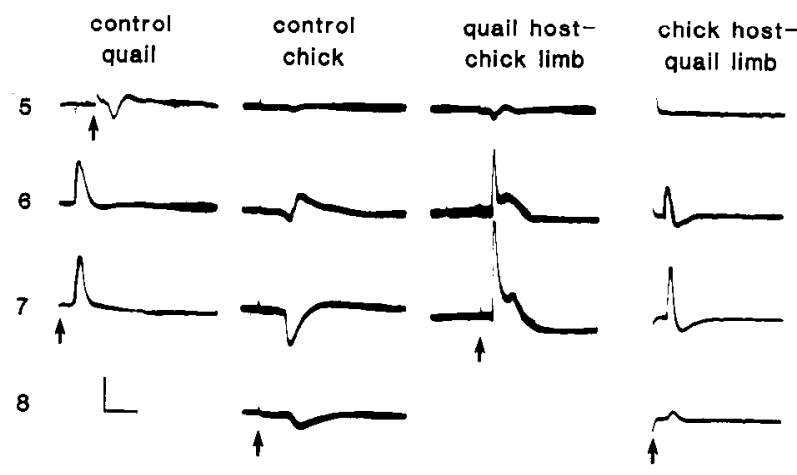

Figure 1. EMG recordings from ischioflexorius $(A)$ and caudilioflexorius $(B)$ muscles at stages $35-37$ in control quail and chick, and quail host and chick host chimera embryos. Stimulation of spinal nerve LS 3 elicited a response from the ischioflexorius in the control quail and quail host-chick limb, whereas the ischioflexorius was activated by LS 3 and 4 in the control chick and chick host-quail limb. The caudilioflexorius contracted when LS 5, 6, and 7 were stimulated in the control quail and quail host-chick limb, and when LS 6, 7, and 8 were stimulated in the control chick and chick host-quail limb. Arrows indicate the time of stimulus. Scales: $20 \mathrm{msec}$ and $0.2 \mathrm{mV}$, except for control quail LS 6 and 7 , where they are $1 \mathrm{mV}$, and for quail host-chick limb LS 5, 6, and 7 in $B$, where they are $0.4 \mathrm{mV}$.

whereas a slightly higher temperature $\left(34^{\circ} \mathrm{C}\right)$ was necessary in quail.

The labeled motoneurons were counted in every third section in serial $10-\mu$ m-thick sections at a total magnification of $\times 630$. Histograms showing the number of labeled cells for each $30 \mu \mathrm{m}$ increment of cord allowed localization of the pool along the anteroposterior axis. To localize a pool in the transverse plane, camera lucida drawings were made for a series of sections at a given level. The sections were aligned by the central canal and the outer boundaries of the white matter, and a dot was made at the position of each stained cell.

\section{Feulgen staining}

To determine the distributions of chick and quail cells in chimeras, we fixed the chimeras in Bouin's solution, dehydrated them in a graded series of ethanol, and embedded them in paraffin. The $10-\mu \mathrm{m}$-thick serial sections were stained with the Feulgen method, which allows chick and quail cells to be recognized by differences in their nuclear chromatin distribution (Le Douarin, 1980, 1982). Six quail embryos that had received a chick limb transplant at stages $17-18 \frac{1}{2}$ were assayed between stages 26 and 28 . We wished to determine how much of the limb was of donor origin at this stage, since this is shortly after axons have invaded the limb buds, forming muscle nerves, and is the period when axons would be expected to respond to limb-derived guidance cues. Two chick embryos with quail limbs were assayed at similar stages. In addition, 2 donor quail limbs were assayed at stages 35-36, confirming that all limb tissue at this stage, including muscle, was of donor origin. 


\begin{tabular}{|c|c|c|c|c|c|c|c|c|}
\hline Muscle & LS 1 & LS 2 & LS 3 & LS 4 & LS 5 & LS 6 & LS 7 & LS 8 \\
\hline \multicolumn{9}{|l|}{ Sartorius } \\
\hline Chick & $\mathrm{X}$ & $\mathrm{X}$ & & & & & & \\
\hline Quail & $\mathrm{X}$ & $\mathrm{X}$ & & & & & & \\
\hline Chick host-quail limb & $\mathrm{X}$ & $\mathrm{X}$ & $\mathrm{x}$ & & & & & \\
\hline Quail host-chick limb & $\mathrm{X}$ & $\mathrm{X}$ & & & & & & \\
\hline \multicolumn{9}{|l|}{ Adductor } \\
\hline Chick & $\mathrm{X}$ & $\mathrm{X}$ & & & & & & \\
\hline Quail & $\mathrm{X}$ & $\mathrm{X}$ & $\mathrm{x}$ & & & & & \\
\hline Chick host-quail limb & $\mathrm{x}$ & $\mathrm{X}$ & $\mathrm{x}$ & & & & & \\
\hline Quail host-chick limb & $\mathrm{X}$ & $\mathrm{X}$ & $\mathrm{x}$ & & & & & \\
\hline \multicolumn{9}{|l|}{ Femorotibialis } \\
\hline Chick & & $\mathrm{X}$ & $\mathrm{X}$ & & & & & \\
\hline Quail & & $\mathrm{x}$ & $\mathrm{x}$ & & & & & \\
\hline Chick host-quail limb & & $\mathrm{X}$ & $\mathrm{X}$ & & & & & \\
\hline Quail host-chick limb & & $\mathrm{X}$ & $\mathrm{X}$ & & & & & \\
\hline \multicolumn{9}{|l|}{ Ischioflexorius } \\
\hline Chick & & & $\mathrm{X}$ & $\mathrm{X}$ & & & & \\
\hline Quail & & & $\mathrm{X}$ & & & & & \\
\hline Chick host-quail limb & & & $\mathrm{X}$ & $\mathrm{X}$ & & & & \\
\hline Quail host-chick limb & & & $\mathrm{X}$ & & & & & \\
\hline \multicolumn{9}{|l|}{ P. iliotibialis } \\
\hline Chick & & & & $\mathrm{X}$ & $\mathrm{X}$ & & & \\
\hline Quail & & & & $\mathrm{X}$ & $\mathrm{X}$ & & & \\
\hline Chick host-quail limb & & & & $\mathrm{x}$ & $\mathrm{x}$ & & & \\
\hline Quail host-chick limb & & & & $\mathrm{X}$ & $\mathrm{X}$ & & & \\
\hline \multicolumn{9}{|l|}{ Caudilioflexorius } \\
\hline Chick & & & & & & $\mathrm{X}$ & $\mathrm{X}$ & $\mathrm{X}$ \\
\hline Quail & & & & & $\mathrm{x}$ & $\mathrm{x}$ & $\mathrm{x}$ & $*$ \\
\hline Chick host-quail limb & & & & & & $\mathrm{X}$ & $\mathrm{X}$ & $\mathrm{X}$ \\
\hline Quail host-chick limb & & & & & $\mathrm{x}$ & $\mathrm{X}$ & $\mathrm{X}$ & $*$ \\
\hline
\end{tabular}

Innervation patterns for each muscle represent recordings from 3-6 embryos. Symbols: X, large responses from segment; $x$, weak and/or occasional responses from segment; ${ }^{*}$, does not normally innervate the limb in quail.

\section{Results}

\section{Lumbosacral segmental innervation and motoneuron pool} localization in quail embryos

Quail hindlimbs are smaller than chicks' from about stage 30 on (Hamburger and Hamilton, 1951), but they have a very similar arrangement of homologous muscles, as shown in the accompanying paper (Tanaka and Landmesser, 1986). However, unlike the chick hindlimb, which is innervated by 8 lumbosacral segments (LS 1-8), the quail limb receives innervation from only 7 segments, LS 8 projecting posteriorly toward the tail.

In order to determine the segmental distribution of quail motoneurons innervating specific thigh muscles, we recorded EMGs from a series of quail thigh muscles following sequential spinal nerve stimulation at stages 35-37 and compared them with EMGs recorded from chick thigh muscles. In general, the distributions were very similar between the 2 species (Table 1), as previously reported chick distributions indicate (Landmesser, 1978a, b; Landmesser and Morris, 1975). For example, the sartorius and adductor muscles were innervated by LS 1 and 2 in both species; similarly, the femorotibialis was innervated by LS 2 and 3, and the p. iliotibialis by LS 4 and 5 in both chick and quail.
In contrast, the segmental innervation of the quail caudilioflexorius differed from that of the chick. In the chick the caudilioflexorius is innervated by LS 6, 7, and 8; however, in the quail, where LS 8 does not innervate the limb, the innervation is shifted anteriorly, LS 5, 6, and 7 contributing (Fig. $1 B$ ). The innervation of the ischioflexorius (Fig. $1 A$ ), the muscle immediately adjacent to the caudilioflexorius, is also shifted; in the chick it is innervated by LS 3 and 4, whereas LS3 alone contributes in the quail. The innervation of the intervening accessory muscle is also shifted, arising from LS 5 and 6 in the chick and in the quail from predominately LS 4 and 5, with a small contribution from LS 6 . (The accessory muscle data are not included in Table 1 because we did not determine the innervation of this muscle in chick-quail chimeras.)

While FMG recording provides a good estimation of segmental motoneuron distribution within the cord, it does not provide a detailed distribution of motoneurons innervating each muscle. We therefore determined the spatial distribution of several motoneuron pools (sartorius, adductor, and caudilioflexorius) by retrograde labeling with HRP.

Confirming the electrophysiological data, motoneurons innervating the quail sartorius and adductor were found predominately in LS 1 and 2 (Fig. 2). In the chick the sartorius pool is situated more anteriorly than the adductor, arising from the 


\section{A. Rostrocaudal Position}

QUAIL SARTORIUS

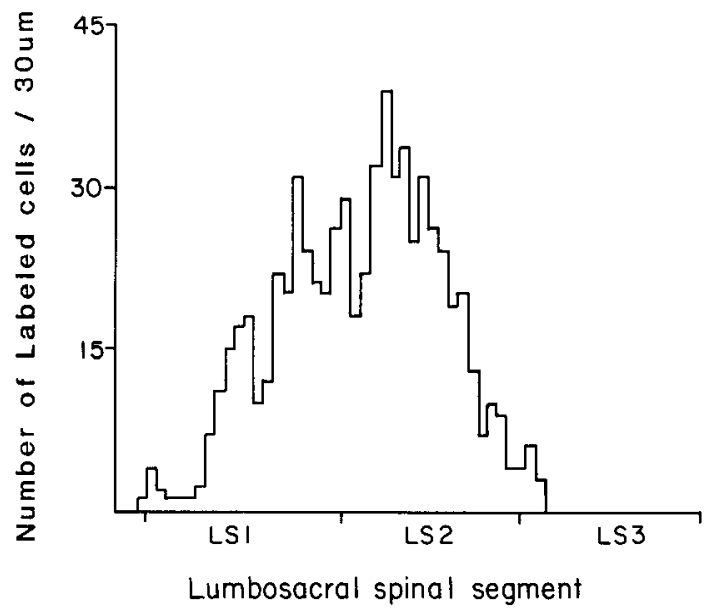

QUAIL ADDUCTOR

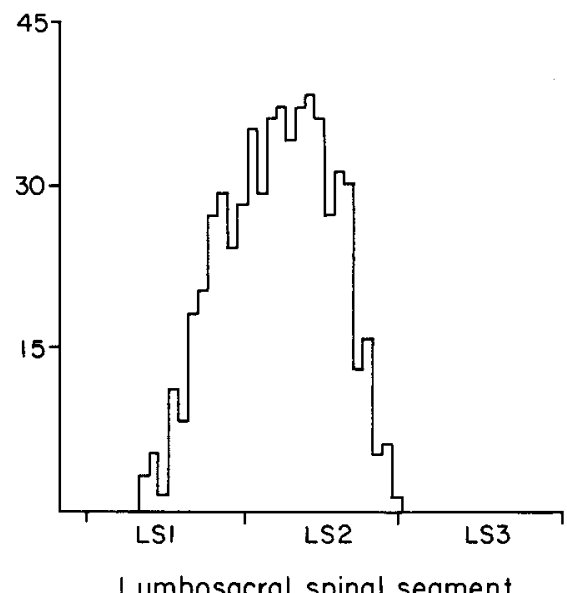

Lumbosacral spinal segment

\section{B. Transverse Position}

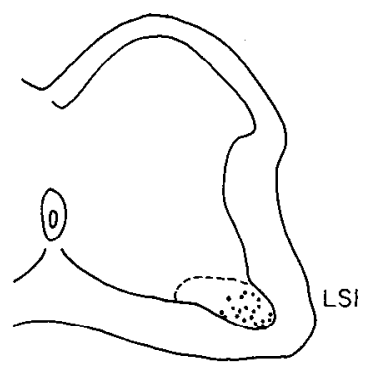

Figure 2. Location of motoneuron pools projecting to the control quail sartorius and adductor muscles. $A$, Histograms indicate rostrocaudal position of HRP-labeled motoneurons following injection of a stage 37 sartorius and a stage 36 adductor. $B$, Camera lucida drawings of cross sections of the cord, showing position of labeled motoneurons in transverse plane. posterior half of the last thoracic segment through the anterior half of LS 2. The adductor pool begins only in the posterior half of LS 1 and extends through all of LS 2, a small number of cells even occurring in LS 3 (Landmesser, 1978a). Figure $2 A$ shows that a similar relationship was found for the quail sartorius and adductor pools. The camera lucida drawings in the same figures indicate that for the quail and chick, both motoneuron pools had similar distributions in the transverse plane of the cord as well, the adductor pool being situated medially, the sartorius laterally (Fig. 2B).

The caudilioflexorius pool was situated laterally in both the chick and quail, but, supporting electrophysiological results, the quail pool was shifted anteriorly. In the chick, most of the caudilioflexorius motoneurons are located in LS 7 and 8 , with only a small proportion (less than 10\%) in LS 6 (Landmesser, 1978a, b). In the quail, caudilioflexorius motoneurons are mainly located in LS 6 and 7, the proportion in LS 6 being substantial (Fig. 3, $A, B$ ). Although EMG recordings indicated that LS 5 also innervated the caudilioflexorius in the quail, albeit to a minor extent, we failed to label any neurons in LS 5 following HRP injection into the muscle. This is probably because we had intentionally reduced the size of the HRP injections to prevent leakage to adjacent muscles. Nevertheless, based on both EMG data and retrograde labeling, it is clear that the main segmental source of innervation for this muscle is shifted anteriorly in the quail. In summary, despite slight anterior shifts for several muscles, the position of quail motoneuron pools was similar to homologous chick pools in both anterior-posterior and mediolateral position.
Segmental innervation and motor pool location in chick-quail chimeras

We tested whether chick motoneurons, which have been shown to innervate chick limb muscles selectively, could inncrvatc homologous quail muscles selectively. The size difference between chick and quail limb buds at early developmental stages is not as great as at older stages, and it is therefore possible to make chick-quail chimeras that possess a hindlimb of the opposite species in which motoneuron projection patterns can be examined.

We found that chick motoneurons selectively innervated homologous muscles in the quail with considerable precision. For example, the quail sartorius and adductor were innervated by chick LS 1 and 2, the femorotibialis by LS 2 and 3, and the p. iliotibialis by LS 4 and 5 (see Table 1). Similar observations were made for quail motoneurons innervating chick limbs. Of special interest are the ischioflexorius and caudilioflexorius, because their segmental innervation pattern is different in quail and chick. We found that the quail ischioflexorius was innervated primarily by chick motoneurons in segments LS 3 and 4, the position of the normal chick ischioflexorius pool (Fig. 1A). It should be recalled that the quail ischioflexorius pool is normally restricted to LS 3. Indeed, when quail cords innervated chick limbs, only LS 3 projected to the ischioflexorius (Fig. 1 $A$ ). Similarly, the quail caudilioflexorius was innervated by chick motoneurons in the normal position of the chick caudilioflexorius pool (LS 6, 7, 8; Fig. 1B); in quail, the caudilioflexorius pool is located in LS 5, 6, and 7, and it was these segments that 
A. Rostrocaudal position

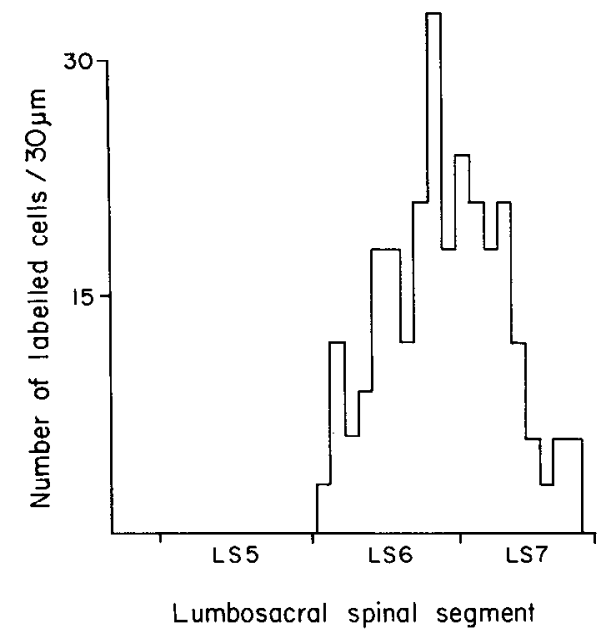

Lumbosacral spinal segment

\section{B. Transverse position}

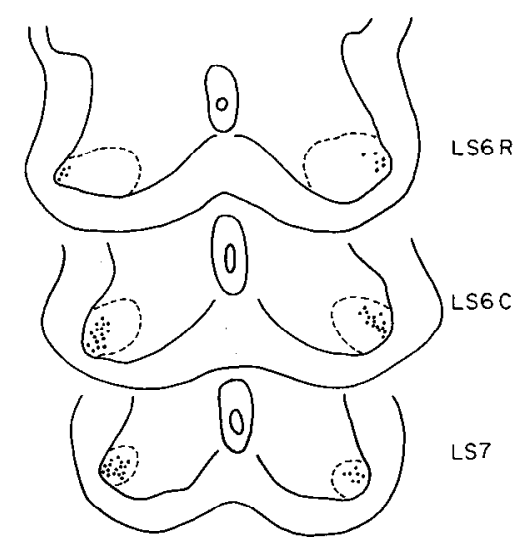

Figure 3. Quail caudilioflexorius. Location of the motoneuron pool innervating the control quail caudilioflexorius muscles at stage $36 \frac{1}{2}$. A, Histogram indicates the rostrocaudal position of HRP-labeled motoneurons on the right side. $B$, Camera lucida drawings of cross sections of the cord, showing the position of labeled motoneurons in the transverse plane. (LS 6R and LS 6C correspond to the rostral and caudal portions of segment LS 6, respectively.) contributed to the innervation of the chick caudilioflexorius in chimeras. In summary, these results indicate that chick and quail motoneurons selectively innervated homologous muscles in limbs of the opposite species.

Further support for this possibility was obtained by determining motoneuron pool position via retrograde labeling with HRP. In 12 chimeric embryos we injected the same muscles in both limbs and assayed motoneuron pool position. An example of chick motoneuron pools innervating chick host and transplanted quail sartorius muscles in one such embryo is shown in Figure 4. It is clear that the 2 pools are situated in very similar positions, localized in LS 1 and 2 along the anteroposterior axis, in an extreme lateral position in LS 1, then shifting more medially in LS 2 (Fig. $4, A, B$ ). This is the normal location of the chick sartorius pool (Landmesser, 1978a, b). Another example is shown in Figure 5, where in this case quail motoneurons that innervate the chick adductor are found more medially in the

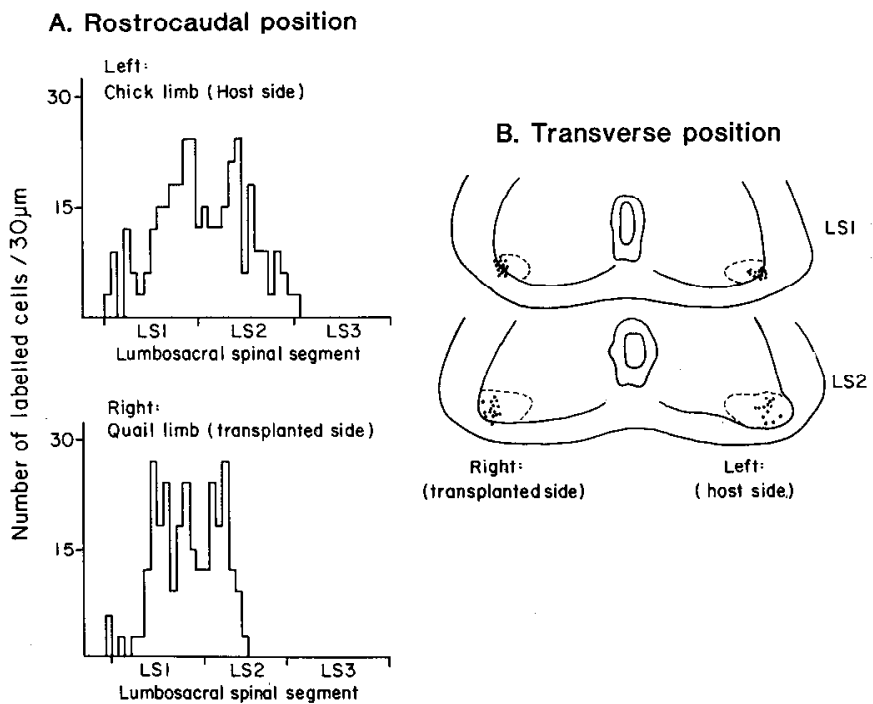

Figure 4. Chick sartorius pools in chimera. Location of chick motoneuron pools innervating the sartorius muscles in a chick host left limb and in a transplanted quail right limb. Both sartorius muscles of a stage 35 chick host, which had received a stage 18 quail limb transplant at stage 18 , were injected with HRP. $A$, Histograms indicate rostrocaudal position of HRP-labeled motoneurons. $B$, Camera lucida drawings of cross sections of the cord, showing the position of motoneurons in transverse plane. normal location of the quail adductor. Similar results were found for the other 7 embryos that were injected.

We can therefore conclude that chick motoneuron pools selectively innervate homologous muscles in the quail limb and that quail motoneurons behave similarly when growing into a chick limb.

\section{Motoneuron activation patterns in chick-quail chimeras}

Additional support for the proposition that chick motoneurons innervate homologous quail muscles with considerable precision was obtained by assaying the activation patterns of these motoneurons during movement sequences. It has previously been shown in isolated chick spinal cord-hindlimb preparations that many of the muscles are activated in a highly characteristic manner during walking-like movement sequences, which are elicited by thoracic or cervical cord stimulation (Landmesser and O'Donovan, 1984a). It was also found that when chick motoneuron pools innervate foreign chick muscles, they develop their original activation patterns. For example, sartorius motoneurons projecting to a caudilioflexorius muscle are still activated with the characteristic sartorius pattern (Landmesser and O'Donovan, 1984b).

We therefore recorded EMGs in isolated spinal cord-hindlimb preparations obtained from chicks, quails, and 3 chickquail chimeras. Figure $6 A$ shows a typical control chick sequence with alternating activity in the sartorius (a flexor) and antagonistic caudilioflexorius (an extensor). We did not extensively characterize normal quail motoneuron pool activation. However, of the quail muscles that we assayed, all were found to behave similarly to homologous muscles in the chick. Quail muscles activated as extensors were the caudilioflexorius, p. iliotibialis, femorotibialis, adductor, and ischioflexorius, whereas the sartorius and anterior iliotibialis were activated as flexors.

We then recorded in chick-quail chimeras from the following 4 quail muscles that were innervated by chick motoneurons: sartorius, femorotibialis, ambiens, and p. iliotibialis. In all cases, we found the activation patterns indistinguishable from normal chick patterns. This can be seen in the example shown in Figure $6 B$, where the quail sartorius is activated with a typical sartorius activation pattern (compare with Fig. $6 A$ ), exhibiting a long silent period during extensor activation. In this case the sartorius is clearly activated out of phase with the contralateral chick caudilioflexorius. In isolated cord preparations, homologous muscles in both limbs are activated in tight synchrony, allowing for easy comparison between limbs (Landmesser and O'Donovan, 1984a). If any extensor motoneurons, or flexor motoneurons with shorter silent periods, had innervated the sartorius, 


\section{A. Rostrocaudal Position}
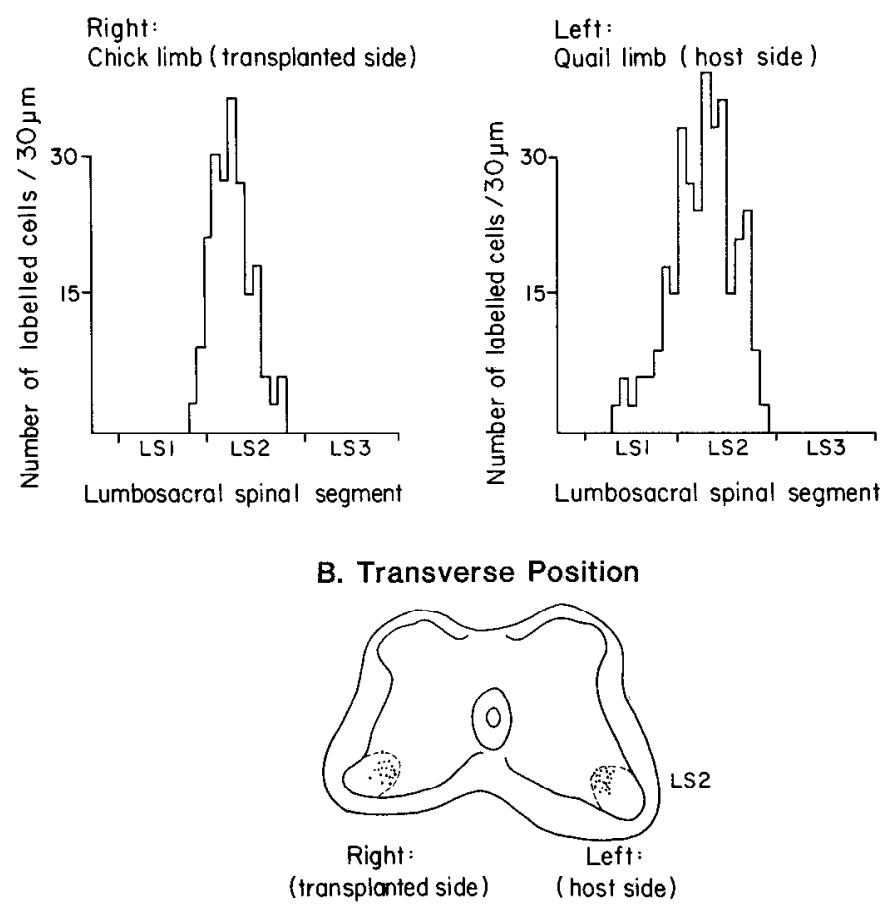

Figure 5. Quail adductor pools in chimera. Location of quail motoneuron pools innervating the adductor muscles in a quail host limb (left) and in transplanted chick limb (right). Both adductor muscles of a stage $35^{1 / 2}$ quail host, which had received a stage $17^{1 / 2}$ chick limb transplant at stage 18 , were injected with HRP. $A$, Histograms indicate rostrocaudal position of HRP-labeled motoneurons. $B$, Camera lucida cross section of the cord, showing the position of labeled motoneurons in the transverse plane.

they would have been activated during the silent period and should have been easily detectable. In addition, since the sartorius is the only chick muscle with such a long silent period (approximately $500 \mathrm{msec}$ ) and long burst durations ( $>2 \mathrm{sec}$ ), the observation of such activation patterns in the quail sartorius is strong evidence that this muscle was innervated essentially cxclusivcly by sartorius motoncurons.

\section{Determination of the species origin of components in transplanted limbs in chimeric embryos}

The results presented thus far provide evidence that motoneurons of one species are able to recognize cues of the sccond species, using these to project to homologous muscles in the transplanted limb. However, it is still possible that the growth cones of, for example, chick motoneurons were not responding to quail cues but to chick signals laid down by chick somite cells that had migrated into the limb to form muscle (Chevallier et al., 1977). Since quail cells can be distinguished from chick cells by Feulgen staining due to their more condensed nuclear chromatin (Le Douarin, 1980, 1982), we examined chimeric limbs in both quail and chick hosts.

We found in all cases that the boundary between cells derived from host and those from the transplanted limb was sharp and coincided with the base of the limb (Fig. 8). In general, the hosttransplant boundary extended from the indentation at the dorsal base of the limb and ran in a ventral-medial direction toward the mesonephros. As shown in the example in Figure 7, quail host tissue surrounded the proximal spinal nerve (Fig. 7d), but the tissue adjacent to the nerve in the plexus region was essentially all of donor or chick origin (Fig. $7 c$ ). Since it is difficult to visualize nerves with the Feulgen stain at low magnification,
A.

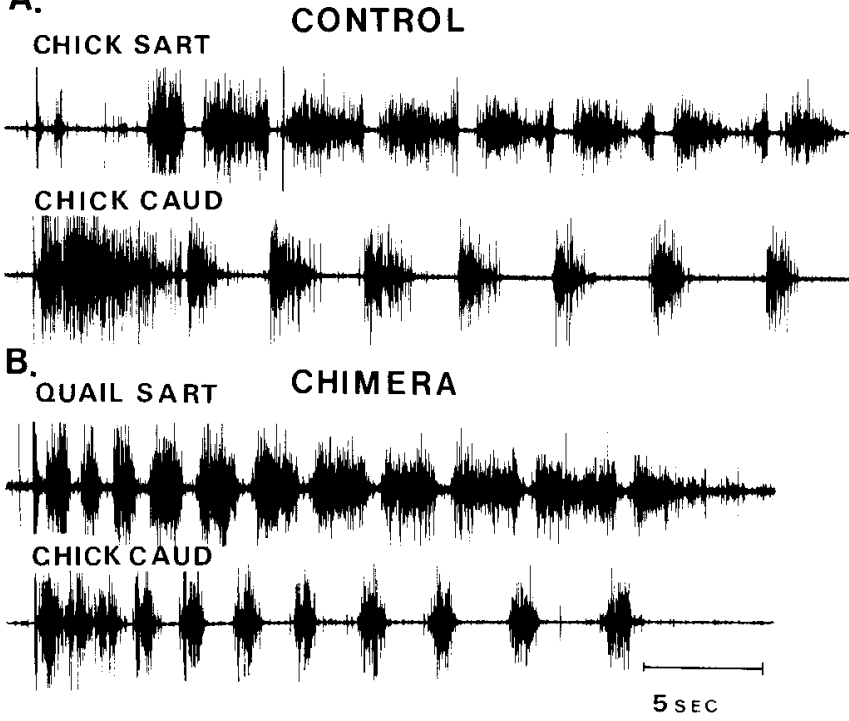

Figure 6. EMG activity recorded from hindlimb muscles in the isolated cord preparations; control chick $(A)$ and chick host-quail limb chimera $(B)$. The sartorius muscle in transplanted quail limb is clearly activated out of phase with the contralateral chick caudilioflexorius in the same manner as the control shown in $A$. During a series of hindlimb movements elicited by a single stimulus to the cervical cord at the beginning of the trace, the sartorius muscle in transplanted quail limb is activated out of phase with the contralateral chick caudilioflexorius in the same manner as in the control shown in $A$. It should be noted that there is often coactivation at the start of a movement sequence and that good alternation takes several cycles to develop.

a comparable section from a plastic-embedded embryo is shown in Figure $7 b$, where the lighter-staining nerves in the plexus region (p) are readily apparent. Although mesenchyme cells distal to the transplant boundary were all of donor origin, nuclei of host origin were common within the nerve proper and appear to be glial cells that had migrated out along the nerves. Also, in most cases, the host-donor boundary in the skin was located more distally than that for the internal tissue (Fig. $7 a$, arrow).

These results indicate that by the stages the limbs were trans; planted (stages 17-181/2), they had already been populated by somitic cells and that subsequent migration of host cells of somitic or other origin was minimal (see also C. Lance-Jones and C. Lagenaur, unpublished observations, 1986). In some cases, a few quail nuclei were found slightly distal to the host-transplant boundary, as indicatcd by arrows in Figure $8 b$. The boundary was also located slightly more distally at posterior levels, as would be predicted from the anterior-to-posterior sequence in the onset of somite cell migration into the limb. Thus, while some of the most posterior proximal thigh was of host origin, the cells surrounding the sciatic and crural plexuses and virtually all of the mesodermal cells within the limb proper were of donor origin.

Since distinction between quail and chick nuclei is more difficult at the later stages (stage 36) used to assess specificity of innervation, most of these limbs were not subjected to Feulgen staining. Nevertheless, since these embryos had been operated at the same stages and with the same surgical technique as the Feulgen-stained series, we are reasonably confident that these limbs were also composed of essentially donor tissue.

\section{Discussion}

Segmental motoneuron innervation patterns and motoneuron pool distributions for quail thigh muscles were very similar to those previously described for the chick (Hollyday, 1980, Land- 


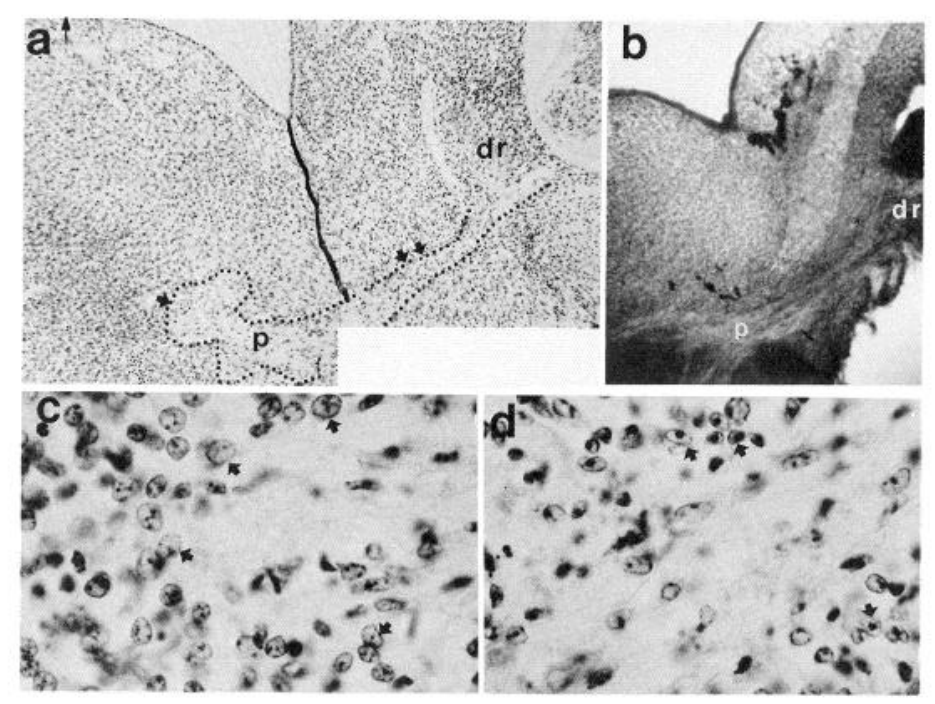

Figure 7. Boundary between host and transplant tissue in a chimera. $a$, Transverse, Feulgen-stained section through the lumbar region of a stage 26 quail host that had received a stage 18 chick limb transplant at stage 17 . The dotted line indicates the spinal nerve and plexus. The boundary between host and transplant tissue (solid line) occurs at the limb base slightly proximal to the plexus region, although host skin cells have grown out further into the limb (their distal extent is indicated by an arrow). $b$, Plastic section from a similarly staged embryo at the same level to show more clearly the course of the spinal nerve and position of the plexus with respect to the limb base. $d r$, dorsal root ganglion; $p$, plexus. $c$ and $d$, Higher magnification views of part of Figure 8 to show the nuclear differences that allow chick and quail cells to be distinguished. $c$ is from the plexus region in $a$, its approximate position being denoted by an arrow. The cells bordering the plexus all contain the dispersed chromatin characteristic of chick nuclei (some are indicated by arrows). $d$ is from a more proximal level, indicated by double arrows in $a$, and shows that the cells surrounding the spinal nerve at this level all contain the condensed chromatin characteristic of quail cells (see arrows).

messer, 1978a). The motoneuron pools for homologous muscles are situated in similar relative positions in most tetrapods (see Bennett, 1983, for review), the quail being no exception. Lateral pools project to muscles derived from the dorsal muscle mass, medial pools to muscles derived from the ventral muscle mass. In addition, anterior pools tend to innervate anterior muscles; posterior pools, posterior muscles.

In contrast, the number of spinal segments innervating limbs is quite variable. For example, the chick hindlimb is innervated by 8 spinal segments, the pigeon and quail by 7 , and the ostrich by 11 (Streeter, 1904). The number of spinal segments that innervate a limb appears to be correlated with the number of somites adjacent to the limb bud at the time of axon outgrowth, and therefore to the relative size of the limb along the anteriorposterior axis.

In this study, we showed that chick (or quail) motoneuron pools were able to selectively innervate homologous muscles in the opposite species with considerable precision. This is consistent with recent, less direct evidence (Kinutani and Le Douarin, 1985) indicating relatively normal behavior of hatched chicks following quail neural tube transplants in the wing region. Our observations lead us to conclude that chick and quail must have similar chemical cues in their limbs and common detector systems for those cues on their motoneuronal growth cones. This might be expected, as these are 2 rather closely related species. Indeed; out of more than 100 monoclonal antibodies raised against chick spinal cord, and which stained chick neuronal tissue either alone or in combination with other tissues, only 1 antibody was found that did not cross-react with quail (H. Tanaka, unpublished observations). Since this antibody stained neuronal fibers, it should be a useful marker for following chick fiber projections in chick-quail chimeras.

Since previous studies have shown that axons sort out in the plexus region at the base of the limb to occupy characteristic positions based on their identity (Lance-Jones and Landmesser, $1981 \mathrm{a}, \mathrm{b})$, it is possible that axons entering the transplanted limbs had already accomplished this by responding to proximal host-derived cues. Clearly, the plexus region of the transplanted limbs appeared to be entirely of donor origin. However, we cannot exclude the possibility that a small number of undetected host cells were responsible for the initial sorting out of axons in the plexus region. Nevertheless, evidence based on limb manipulations (Lance-Jones, 1986; Lance-Jones and Landmesser, 1981b; Whitelaw and Hollyday, 1983), as well as on the behavior of growth cones in control limbs $(K$. Tosney and $L$. Landmesser, unpublished observations), strongly suggests that additional cues within the limb are required for axons to project to their correct targets. Since the transplanted limbs were entirely of donor origin, we conclude that whatever cues are used by axons in the avian limb, including target-specific as well as less specific permissive cues, these must be readable by the motoneuron growth cones of a related species.

In attempting to understand the way in which such recognition molecules may be distributed, it is especially interesting to consider the innervation patterns we observed in chimeras for muscles whose segmental innervation differs between the 2 species (i.e., the caudilioflexorius and ischioflexorius). Several recent studies have suggested a segmental basis for such recognition molecules. Preganglionic autonomic fibers in rodents have been shown to have a preference for innervating autonomic ganglion cells (Nja and Purves, 1977a, b; Purves et al., 1981) or even transplanted intercostal muscles (Wigston and Sanes, 1985) from similar segmental levels. Furthermore, Beresford (1983) has shown that individual chick wing muscles are derived from a characteristic subset of the somites that contribute to the wing, and these muscles in turn appear to be innervated by neurons from the segmental levels (Landmesser, 1984) adjacent to those somites. Similar observations have recently been made for the chick hindlimb (C. Lance-Jones and C. Lagenaur, unpublished observations, 1986). Thus, it has been hypothesized that an early determinative event assigns the same positional values (Wolpert et al., 1975) to cells at each segmental level.

What sort of innervation pattern would be expected if positional markers were assigned on a rigid segmental basis? If the 


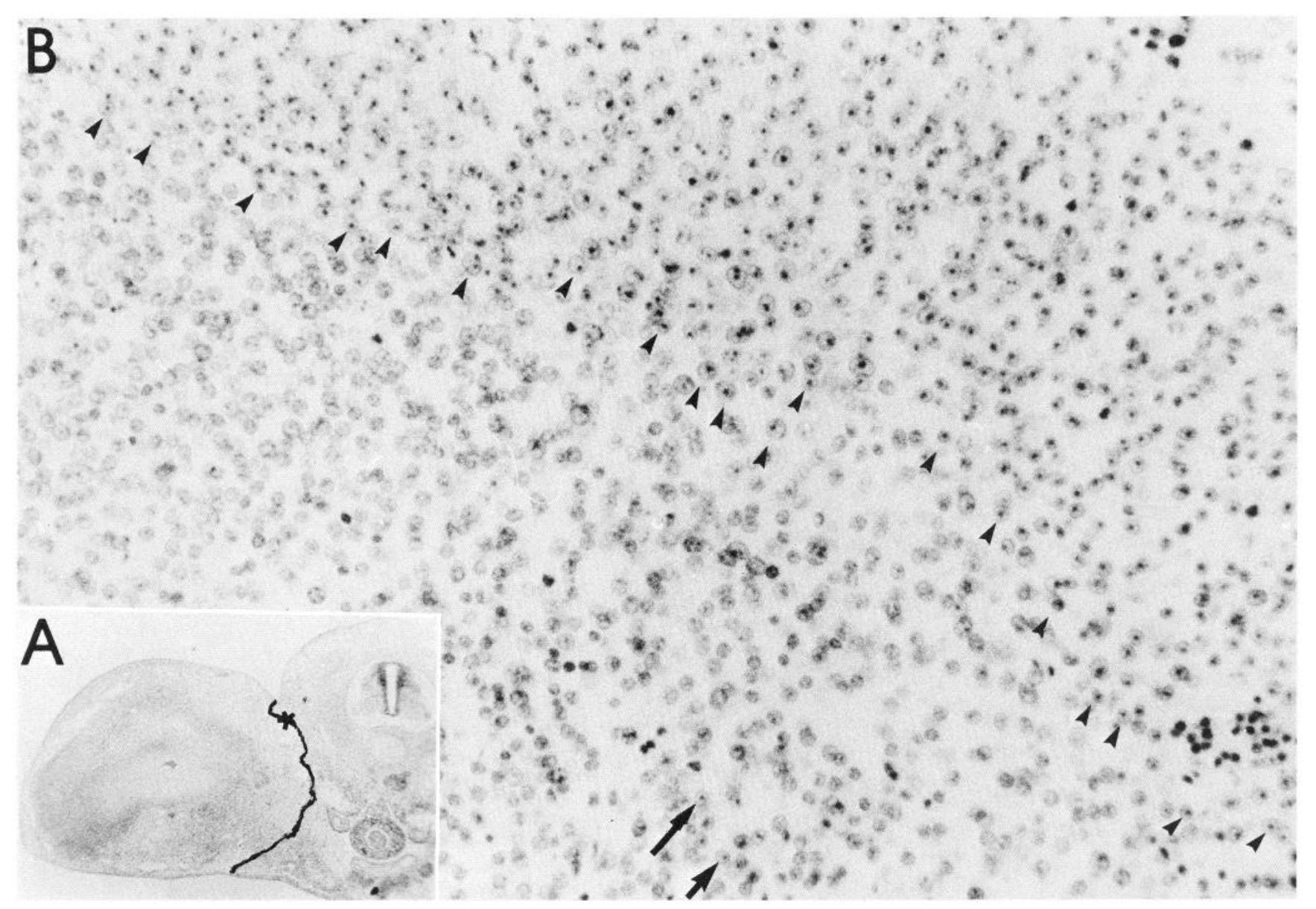

Figure 8. A, Transverse Feulgen-stained section of lumbar region from another stage 26 quail host that had received a stage 19 chick limb transplant at stage 17. B, Higher magnification of the region indicated by the asterisk in $A$. Host quail cells (characterized by more condensed chromatin) formed a clear boundary with the transplanted chick limb (arrowheads). This boundary is indicated by a line in the inset in $B$. A few host quail cells that had migrated a short distance into the chick limb are indicated by arrows. $A, \times 25 ; B, \times 370$.

somitic contribution patterns observed for the wing (Beresford, 1983) hold for the hindlimb, as they appear to (C. Lance-Jones and C. Lagenaur, unpublished observations, 1986), we would expect the quail caudilioflexorius to have markers for LS 5, 6 , and 7. Thus, we might expect that chick neurons in LS 5, 6, and 7 would innervate this quail muscle. However, we found that the entire chick caudilioflexorius pool, primarily in LS 7 and 8 , innervated the quail muscle. Similarly, the chick caudilioflexorius was innervated by quail motoneurons in LS 5, 6, and 7. A similar set of observations was made for the ischioflexorius, which receives innervation from LS 3 and 4 in the chick but only from LS 3 in the quail.

These observations are not consistent with a model in which positional values are assigned on a strict segmental basis or with one in which growth cones simply track along and/or selectively innervate somite cells derived from the same segmental level. They would, however, be consistent with a model in which an entire set of positional values is assigned along the anteriorposterior extent of the row of cells (neural tube, somite, etc.) adjacent to the limb or limb field. Thus, if the distribution of values were relative, a different absolute number of somites or spinal segments would not be relevant, and we would expect the most posterior cells to bear the most extreme value in both quail and chick. This would be compatible with chick caudilioflexorius motoneurons selectively innervating a quail caudilioflexorius muscle composed of a different somitic complement. It is also possible that positional labels are borne not by the somitic cells themselves, but by the connective tissue components derived from the lateral plate mesoderm. However, again, similar reasoning to that followed above would suggest that these cells must also bear labels that are distributed in a relative manner across the entire anteroposterior extent of the limb bud, rather than on a segmental basis.

C. Lance-Jones and C. Lagenaur (unpublished observations, 1986) have recently directly tested whether somite cells bear labels that allow them to be recognized by motoneurons from the same segmental level. They found for chick hindlimb muscles a good correspondence between the segmental source of muscle precursor cells and of innervation. However, following surgical reversal of strips of somites along the anterior-posterior axis, motoneurons were found to innervate their original muscles even though these were now populated by somite cells from different segmental levels. Their results indicate that if somite cells bear recognition markers, they must obtain these after populating the limb bud. Alternatively, they suggest that the markers may actually be borne by the non-muscle connective tissue components of the limb. Our observations are compatible with either possibility with the proviso that positional values be assigned in a coordinate manner across the entire limb field.

Since chick and quail are closely related, we do not know whether interspecies selective innervation will occur in more distantly related species (see also Harris, 1980). However, the fact that such selective innervation occurs may be relevant to the rapidly developing area of brain implants (Bjorklund et al., 
1983). If suitable embryonic tissue of the same species is not available for implant, similar tissue from a closely related species might be used. Finally, since we have obtained selective interspecies innervation of homologous muscles that differ markedly in size, we can test the hypothesis that cell death serves primarily to quantitatively match a neuronal population with its target. This is the topic of the subsequent paper (Tanaka and Landmesser, 1986).

\section{References}

Alvarado-Mallart, R.-M., and C. Sotelo (1984) Homotopic and heterotopic transplantations of quail tectal primordia in chick embryos: Organization of the retinotectal projections in the chimeric embryos. Dev. Biol. 103: 378-398.

Bennett, M. R. (1983) Development of neuromuscular synapses. Physiol. Rev. 63: 915-1048.

Beresford, B. (1983) Brachial muscles in the chick embryo: The fate of individual somites. J. Embryol. Exp. Morphol. 77: 99-116.

Bjorklund, A., U. Stenevi, R. H. Schmidt, S. B. Dunnett, and F. H. Frage (1983) Intracerebral grafting of neuronal cell suspensions. Acta Physiol. Scand. [Suppl.] 522: 1-75.

Chevallier, A., M. Kieny, and A. Mauger (1977) Limb-somite relationship: Origin of the limb musculature. J. Embryol. Exp. Morphol. 41: 245-258.

Ferguson, B. A. (1983) Development of motor innervation of the chick following dorsal-ventral limb bud rotations. J. Neurosci. 3: 17601772.

Fraser, S. E., and R. K. Hunt (1980) Retinotectal specificity: Models and experiments in search of a mapping function. Annu. Rev. Neurosci. 3: 319-352.

Hamburger, V., and H. Hamilton (1951) A series of normal stages in the development of the chick embryo. J. Morphol. 88: 49-92.

Harris, W. A. (1980) The effects of eliminating impulse activity on the development of the retinotectal projection in salamanders. J. Comp. Neurol. 194: 303-317.

Heaton, M. B. (1973) Xenoplastic eye transplantation between chick and quail embryos: Some neuroanatomical and functional aspects. J. Comp. Neurol. 151: 359-376.

Hollyday, M. (1980) Organization of motor pools on the chick lumbar motor column. J. Comp. Neurol. 194: 143-176.

Hollyday, M. (1983) Devclopment of motor innervation of chick limb. In Limb Development and Regeneration, J. F. Fallon and A. I. Caplan, eds., pp. 183-193. Alan R. Liss, New York.

Kinutani, M., and N. Le Douarin (1985) Avian spinal cord chimeras. I. Hatching ability and posthatching survival in homo-heterospecific chimeras. Dev. Biol. 111: 243-255.

Lance-Jones, C. (in press) Motoneúron connectivity in embryonic chick limbs with an altered complement of muscle. Dev. Biol.

Lance-Jones, C., and L. Landmesser (1980a) Motoneurone projection patterns in embryonic chick limbs following partial deletions of the spinal cord. J. Physiol. (Lond.) 302: 559-580.

Lance-Jones, C., and L. Landmesser (1980b) Motoneurone projection patterns in the chick hind limb following early partial reversals of the spinal cord. J. Physiol. (Lond.) 302: 581-602.

Lance-Jones, C.. and L. Landmesser (1981a) Pathway sclection by chick lumbosacral motoneurons during normal development. Proc. R. Soc. Lond. [Biol.] 214: 1-18.

Lance-Jones, C., and L. Landmesser (1981b) Pathway selection by embryonic chick motoneurones in an experimentally altered environment. Proc. R. Soc. Lond. [Biol.] 214: 19-52.

Landmesser, L. (1978a) The distribution of motoneurones supplying chick hind limb muscles. J. Physiol. (Lond.) 284: 371-389.

Landmesser, L. (1978b) The development of motor projection patterns in the chick hind limb. J. Physiol. (Lond.) 284: 391-414.

Landmesser, L. (1984) The development of specific motor pathways in the chick embryo. Trends Neurosci. 7: 336-339.

Landmesser, L., and D. G. Morris (1975) The development of functional innervation in the hind limb of the chick embryo. J. Physiol. (Lond.) 249: 301-326.

Landmesser, L., and M. O'Donovan (1984a) Activation patterns of embryonic chick hind limb muscles recorded in ovo and in an isolated spinal cord preparation. J. Physiol. (Lond.) 347: 189-204.

Landmesser, L., and M. O'Donovan (1984b) The activation patterns of embryonic chick motoneurones projecting to inappropriate muscles. J. Physiol. (Lond.) 347: 205-224.

Le Douarin, N. (1980) The ontogeny of the neural crest in avian embryo chimeras. Nature 286: 663-669.

I.e Douarin, N. (1982) The neural crest. In Developmental and Cell Biology Series, Vol. 12, P. W. Barlow, P. B. Green, and C. C. Wylie, eds., Cambridge U. P., New York.

$\mathrm{Nja}, \mathrm{A}$, and D. Purves (1977a) Specific innervation of guinea pig superior cervical ganglion cells by preganglionic fibers arising from different levels of the spinal cord. J. Physiol. (Lond.) 264: 565-583.

$\mathrm{Nja}, \mathrm{A}$., and D. Purves (1977b) Reinnervation of guinea pig superior cervical ganglion cells by preganglionic fibers arising from different levels of the spinal cord. J. Physiol. (Lond.) 272: 633-651.

Purves, D., W. Thompson, and J. W. Yip (1981) Reinnervation of ganglia transplanted to the neck from different levels of the guinea pig sympathetic chain. J. Physiol. (Lond.) 313: 49-63.

Stirling, R. V., and D. V. Summerbell (1983) Familiarity breeds contempt: The behavior of axons in foreign and familiar environments. In Limb Development and Regeneration, Pt. A, J. F. Fallon and A. I. Caplan, Eds., pp. 217-226, Alan R. Liss, New York.

Streeter, G. L. (1904) The structure of the spinal cord of the ostrich. Am. J. Anat. 3: 1-27.

Tanaka, H., and L. Landmesser (1984) The quantitative matching hypothesis of neuronal cell death: A test using chick-quail chimeras. Soc. Neurosci. Abstr. 10:186.7.

Tanaka, H., and Landmesser, L. (1986) Cell death of lumbosacral motoneurons in chick, quail, and chick-quail chimera embryos: A test of the quantitative matching hypothesis of neuronal cell death. J. Neurosci. 6: 2889-2899.

Whitelaw, V., and M. Hollyday (1983) Thigh and calf discrimination in the motor innervation of the chick hindlimb following deletions of limb segments. J. Neurosci. 3: 1199-1215.

Wigston, D. J., and J. R. Sanes (1985) Selective reinnervation of intercostal muscles transplanted from different segmental levels to a common site. J. Neurosci. 5: 1208-1224.

Wolpert, L., J. Lewis, and D. Summerbell (1975) Morphogenesis of the vertebrate limb. In Ciba Foundation Symposium, Vol. 29: Cell Patterning, R. Porter and J. Rivers, eds., pp. 95-130, Elsevier, Amsterdanı. 